Benjamin Fagard, Elena Smirnova, Dejan Stosic, José Pinto de Lima

\title{
Complex Adpositions in Europe and beyond: A synthesis
}

\begin{abstract}
In the chapters of this volume, the authors describe the paradigms of complex nominal relators (CRs for short) in various languages of Europe, both Indo-European (Romance, Germanic, Slavic, Celtic, Greek and Albanian) and non-Indo-European (Estonian and Permic (Finno-Ugric), Basque (isolate), Turkish and Maltese (Afro-Asiatic)). In this final chapter, we propose to go beyond individual descriptions, and discuss the results presented in all chapters from a wider typological perspective.
\end{abstract}

\section{Keywords}

adpositions, case, complex prepositions, nominal relators, typology, constructionalization

\section{Benjamin Fagard}

CNRS, ENS \& Paris Sorbonne Nouvelle; PSL

Lattice laboratory, Ecole Normale Supérieure, 1 rue Maurice Arnoux, 92120

Montrouge, France

benjamin.fagard@ens.psl.eu

Elena Smirnova

Institut de langue et littérature allemandes

Université de Neuchâtel

Espace Tilo-Frey 1

CH-2000 Neuchâtel

elena.smirnova@unine.ch

\section{Dejan Stosic}

University of Toulouse Jean Jaurès \& Laboratory CLLE (CNRS \& UT2J)

5, allées Antonio Machado, 31058 Toulouse Cedex 9, France

dejan.stosic@univ-tlse2.fr

José Pinto de Lima

Universidade de Lisboa, Faculdade de Letras

Rua Professor Simões Raposo, $n^{\circ}$ 20, 3-B, 1600-662 LISBOA, Portugal

pintodelima@outlook.pt 
1 The rise of Complex Nominal Relators - The diachrony of CRs in European languages

In the introductory chapter, we formulated two research questions related to the diachrony of complex adpositions. In what follows, we will take up these questions and elaborate on them, taking into account the situations in the individual languages and language families dealt with in the chapters of this volume.

One of the aims of this volume was to focus more closely on the EMERGENCE AND EVOLUTION of different types of CAs in European languages by gaining more empirical evidence from different languages and on different types of expressions. Our intention was thus to bring together contributions from a varied array of European languages, so that a good picture of the (presumably) complex phenomena leading to the emergence and the evolution of CAs ensues. As mentioned in the introduction, the background has already been laid out in the literature (Lindqvist 1994, Schwenter and Traugott 1995, Di Meola 2000, Cifuentes Honrubia 2003, Hoffmann 2005, Kurzon and Adler 2008, Hagège 2010, Libert 2013, among others). This volume has widened the object under analysis from the traditional one of simple prepositions, widely studied, to the more embracing one of complex adpositions, including other complex nominal relators, especially gaining the advantage of contemplating studies on complex postpositions and combinations of adpositions and case marking. With regard to this goal, the volume adds substantially to the existing body of research on complex prepositions.

First, as concerns the so far most studied syntactic pattern of complex prepositions [P $\mathrm{N} \mathrm{P}$ ], with its less frequent variant with the genitive marking on the complement noun phrase [P N CASE], the chapters on West Germanic and on Romance languages look in more detail at the developmental paths of a series of individual prepositions, as well as at the development of the schematic pattern itself. They show that, on one hand, there is a great amount of variance between the individual adpositions with respect to frequency, to the degree of formal fixedness and to the possibility of modification and omission of individual elements within them. On the other hand, the schematic pattern at a more general level of abstraction seems to be more stable, in that it gains in productivity and attracts an ever larger paradigm of individual adpositions. The chapters on Celtic and Greek, on the other hand, represent a first account of the inventory of Celtic and Greek CAs following this pattern. Most importantly, the observations from these two languages confirm the general developmental regularities which have been taken into account and described for other languages, such as Germanic and Romance. For example, the diachronic processes of unit formation and reanalysis are particularly relevant for the development of complex prepositions of this type, which are sometimes followed by and may thus be considered a prerequisite for the univerbation (in a broad sense) of the erstwhile free syntactic combinations with compositional semantics. On the way from free syntactic combination to complex adposition, syntagmatic fixedness increases, which leads to the formation and entrenchment of a syntagmatic string. During this diachronic process, the individual elements of the syntagm successively become less independent, gradually coalescing into a holistic and idiosyncratic unit (= unit formation). This loss of autonomy of individual elements is often (and quite naturally) accompanied by decategorialization and followed by univerbation. A good example of unit formation followed by univerbation and complete loss of internal structure is the Celtic preposition abalamour da 'because of', which originated in (Medieval or Classical) French par l'amour de 'out of love for' and is often pronounced [blam] in spoken Breton, its etymology thus completely obscured. What we observe here are more or less usual reduction processes commonly found in the processes of grammaticalization and lexicalization.

As concerns other formation patterns of complex prepositions, the individual chapters have revealed a great variety of syntactic and morphological patterns, which, however, display a high degree of similarity at a more general level. For example, the adverbial pattern 
[ADV P] is discussed prominently in chapters on Greek (e.g. andi ja 'instead of', mazi me 'together with', mesa s(e) 'in; inside', ekso apo 'out of; outside' etc.), but is also mentioned in the chapters on West Germanic and Romance languages, where its productivity seems to be weaker and has faded away in the last centuries, most likely due to the spread of the currently dominant [P N P] pattern mentioned above ${ }^{1}$; in Serbian, it is the third most frequent pattern of formation (with 24 CPs formed). Maltese, on the other hand, displays a structure which serves as a main productive pattern to form complex adpositions in this language, the combination of two prepositions [P P], e.g. barra minn 'except', ghal fuq 'unto', minn fuq 'from on', minn taht 'from under'. Remarkably, the patterns [ADV P] and [P P], documented in different languages, behave very much alike in that they form a continuum from free and compositional combinations to non-analyzable holistic (often univerbated) units, suggesting that they follow the same general diachronic tendencies just described for the pattern [P N P]. To give an example, Maltese has a number of univerbated [P P] combinations either with the initial ma' 'with' or initial minn 'from', which obviously originate in free and compositional syntactic combinations but now function as non-analyzable linguistic units (see the chapter on Maltese for details): madwar 'around', matul 'during', minbarra 'except', mingћajr 'without', mintul 'throughout'. In other words, we find once again the stable development from erstwhile free syntactic combinations to more fixed elements - with the recurrent question of where to draw the line: for instance, in the chapter on Serbian, such elements have been considered as noncanonical simple adpositions.

As concerns complex postpositions, the volume shows that several languages have this type of expressions at their disposal. Whether a language has pre- or postpositions in the domain of CAs generally follows from the basic structural characteristics of the language in question. If a language predominantly makes use of prepositions in the domain of simple relators, it will most likely have prepositions in the domain of complex relators. Of course, this rule is not without exceptions, and languages may have several different types of adpositions, like e.g. German, where pre-, post- and circumpositions are attested in both subcategories of nominal relators. Nevertheless, the "normal" situation is that there is one preferred and prototypical type of adpositions in a language, and both, simple and complex relators, show an identical or similar distribution in this respect.

Among the languages described in this volume, there are complex postpositions in Estonian, Turkish, Basque and Permic. They are of different but closely related structural types. It is in the domain of complex postpositions that the distinction between syntactic and morphological complexity becomes interesting. In the case of complex prepositions, which we have focused on above, the diachronic origin is usually a syntactic structure, namely a free syntactic combination with compositional semantics, which in the course of time becomes more and more formally fixed and semantically non-compositional. For most complex postpositions, however, the original structure appears to be a morphologically complex structure. In Permic, for example, the basic morphological structure of the complex postposition consists of a relational noun with case marking [ $\mathrm{N}_{\text {rel- }}$-CASE] (1).

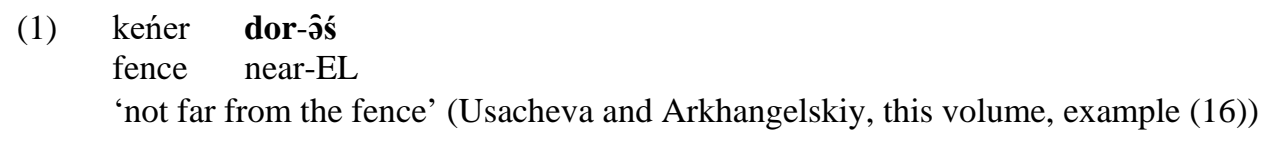

\footnotetext{
${ }^{1}$ The situation in Romance is not homogeneous, however, since Ibero-Romance and, to a lesser extent, ItaloRomance still have a productive paradigm of [Adv P] sequences.
} 
This structure functions as a postposition and assigns case to the preceding complement noun phrase. In the course of the development, the relational noun in the nucleus of the complex postposition gradually loses its ability to inflect - an instance of decategorialization -, and often ends up as a fixed expression which cannot be further modified.

In Basque, the default or canonical construction of a complex postposition is schematically the same as in Permic: [ $\mathrm{N}_{\text {rel- }}$ CASE], e.g. menpe-an = domination-LOC 'under the authority', where the case of the preceding nominal complement is governed by the morphologically complex adposition, whose nucleus is the relational noun (2) (see chapter on Basque for more details).

zuzendari-a-ren menpe-an

(Basque) director-DET-GEN domination-LOC

'under the authority of the director' (Jendraschek, this volume, example (22a))

Diachronically, this construction has undergone reduction processes in several ways, most notably by losing case marking on the relational noun, similarly to the situation in Permic just described.

In Turkish, a similar situation holds: the prototypical productive formation pattern of complex postpositions is [N-(POSS)-CASE], thus analogous to the complex postpositions in Basque and Permic. These morphologically complex postpositions undergo formal and semantic changes over time. On the formal side, the noun present as nucleus loses the ability to take different cases and often ends up as a fossilized form with only one specific and generally nontransparent case marker. On the semantic side, many complex postpositions with spatial semantics develop metaphorical and/or metonymical meanings which are often clearly differentiated from the original spatial meanings by the assignment properties of the postposition itself: whereas the spatial meaning is associated with genitive marking on the preceding complement noun phrase (3), metaphorical uses are associated with the ablative case assignment (4).

(3) ağac-ın yan-ın-da

(Turkish)

tree-GEN side-POSS.3-LOC

'next to the tree'

(4) demokrasi-den yan-a

democracy-ABL side-DAT

'in favor of democracy’ (Jendraschek, this volume, examples (16ab))

In Estonian, a typical complex postposition follows a more complex structure and consists of an inflected relational noun, typically in the genitive case, and a simple postposition, i.e. [ $\mathrm{N}_{\text {rel }} \mathrm{CASE} \mathrm{P}$ ], thus displaying syntactic and morphological complexity at the same time (5).

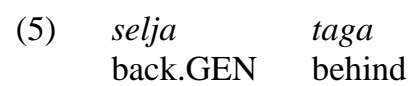

(Estonian)

'behind the back of' (Jürine, this volume, from example (18))

As the development of complex postpositions is very recent in Estonian, there is not enough diachronic evidence to date to reconstruct the developmental paths of these elements in detail. However, available synchronic evidence suggests that Estonian postpositions follow 
developmental paths which are very similar to those of other complex adpositions described above. More specifically, the complex postpositions form a continuum from fully compositional structures to semantically non-compositional, i.e. holistic units, and thus display usual signs of unit formation and lexicalization (see chapter on Estonian for details).

In sum, in all these cases of the attested developments of complex postpositions, very similar general diachronic mechanisms and processes seem to be at work: unit formation, decategorialization, loss of compositionality and analyzability, univerbation and semantic bleaching, or loss of referential meaning. Generalizing over these observations, the diachronic development of complex adpositions and other CRs, prepositions and postpositions alike (and irrespective of the presence of case-marking), appears to be a relatively homogeneous phenomenon, following known and typical mechanisms and paths. In this connection, the present volume has shown that (i) complex adpositions exist in many languages - at least in the languages described here: this could be either a typical feature of European languages, i.e. a Euroversal rather than a universal phenomenon; or it could be that nominal relations naturally come to be marked by complex structures, beyond the widely attested simple markers of nominal relations (case, simple adpositions and relational nouns); (ii) complex adpositions can come in different shapes, with a few typical patterns for European languages, such as [P N P], [P N CASE] or [ADV P], and (iii) irrespective of the main type of adposition found in a given language, i.e. pre-, post- or ambiposition, and of the presence or absence of case marking, they follow similar developmental paths in the course of their history.

The second central question raised in the introductory chapter concerned the conceptual status of the diachronic changes in which complex adpositions are involved and their theoretical modelling in terms of GRAMMATICALIZATION, LEXICALIZATION and/or CONSTRUCTIONALIZATION. The authors of this volume seem to share the idea that complex adpositions arise via the process of grammaticalization. The development of complex adpositions in the languages described here follows typical characteristics of grammaticalization processes, as for example decategorialization, semantic bleaching, syntagmatic coalescence, etc. (see above). Some authors in this volume explicitly mention lexicalization as a possible conceptual embedding of the observed changes, for example Anni Jürine in her chapter on Estonian (see also chapter on West Germanic for a similar view):

It is important to highlight that the main mechanism for semantic change in the development of Estonian (complex) postpositions is lexicalization. Lexicalization, in this case, is defined as a type of language change whereby a 'new contentful' form is created with formal and/or semantic properties that cannot be directly derived from its components (Brinton and Traugott 2005: 96). It must be noted that lexicalization is here taken to be a phenomenon that is not the opposite of the grammaticalization process, but rather the two are taken as processes that complement each other, and which can occur in a single instance of language change. To put it in Lehmann's (2002) terms, lexicalization is here understood as 'adoption into (mental) lexicon', which means that the linguistic item is analyzed holistically, not analytically. (Jürine, this volume)

A significant insight from the discussions presented in this volume is that the authors, as a rule, do not see grammaticalization and lexicalization as conflicting, opposite or complementary processes in which complex adpositions might be involved (see e.g. Moreno Cabrera 1998, Giacalone Ramat and Hopper (eds.) 1998, Brinton and Traugott 2005, Lightfoot 2005, Prévost and Fagard 2007). Rather, they consider these two processes as operating at the same time and in parallel during the development of complex adpositions. Whereas the concept of lexicalization, as creation of new holistically accessed linguistic 
items, i.e. linguistic signs or lexemes, applies to the initial emergence of a new complex adposition in a language, the concept of grammaticalization is applied to the small-scale changes accompanying and following it, leading to the establishment of a linguistic sign with the dedicated grammatical function, i.e. an adposition.

One possible way to reconcile the discussion of the role of lexicalization and/or grammaticalization in the development of complex adpositions is offered by the relatively new concept of constructionalization or constructional change (see esp. chapters on Germanic and Romance). The emergence and increasing productivity of systematic schematic patterns such as [P N P], [P N CASE], [P P] for complex prepositions or $\left[\mathrm{N}_{\text {rel-CASE }}\right]^{2}$ for complex postpositions, which become available for the creation of new CAs, may just as well be conceptualized in terms of constructionalization, i.e. the emergence of a new schematic construction in a language (see also the term "grammaticalization by analogy" in Hoffmann 2004). A pattern often appears to be closely linked to a specific period, in which it emerges, gathers momentum (attracting or producing new constructs); after that, it often ceases to be productive, as is the case with [P N CASE] constructions in Medieval French, or [N CASE] constructions in Modern Serbian.

The issue of univerbation, which featured prominently in most individual chapters of this volume, is closely connected to the important question of the "ultimate" goal category: do complex adpositions constitute an intermediate step on the grammaticalization cline towards simple adpositions and eventually towards case markers? In a very abstract manner, the answer to this question is positive. Since the empirical evidence from different languages indicates that, in many cases, complex adpositions either shed parts or become univerbated, and thus become unanalyzable linguistic units, we can treat the resulting elements as simple adpositions. In this respect, the available evidence corroborates the assumption of the cline complex > simple adposition. Note, however, that there also seems to be a good deal of renewal within the category of CAs, many of which disappear before undergoing univerbation. This can be illustrated with French par l'amour de 'for the love of, thanks to', which was frequent enough in Medieval or Classical French to be borrowed by Breton, but then disappeared altogether from French. In the corpora many examples can be found of individual CAs (i.e. tokens, not types or constructions) that become somewhat frequent, and then disappear, perhaps ousted by a new wave (see e.g. the chapter on Romance for more examples).

The development of the German preposition wegen 'due to' is a good example of the 'shedding strategy' (see chapter on Germanic for details). Rottet (this volume) notes the existence of a "grammaticalization cycle" from morphologically complex to simplex preposition in Celtic. As in the case of a-enep 'against' (6), a complex adposition based on the simple preposition $d a$ 'to' and a lost noun presumably meaning 'face' (cf. Welsh wyneb 'face'), some of the complex prepositions "come to function like simplex prepositions, taking personal inflections directly” (Rottet, this volume).

(6) en da enep 'in your against'

$\rightarrow$ a-enep dit 'against to-you'

$\rightarrow$ enepdout 'against.2SG'

(Celtic)

For Basque, Jendraschek (this volume, (1)) reconstructs a "continuum of grammaticalization" with three consecutive stages leading from complex to simple adposition and eventually to case marker (7).

\footnotetext{
${ }^{2}$ A recurrent pattern in Serbian (and other Slavic languages), which yields items generally analyzed as secondary prepositions: (Serbian) krajem + GEN 'by the end of' (kraj 'end'), vrh + GEN 'above' ( $v r h$ 'top'), etc.
} 
$>\mathrm{N}_{\text {case }}\left[\mathrm{N}_{\mathrm{rel}}-\varnothing\right]_{\mathrm{P}}$ (legearen arabera 'according to the law')

$>\mathrm{N}$ [CASE] (etxe-an 'in the house'). (Jendraschek, this volume, Figure (2))

First, adpositions emerge and are usually identifiable within a relevant construction. In the intermediate stage, the adposition is no longer complex and is juxtaposed to its nominal complement. In the final stage, grammaticalization has reached its endpoint and the adposition has become bound and turned into a case suffix. For Romance languages, it can also be said that some of the older CAs grammaticalize into simple non-analyzable adpositions, even though univerbation does not always show up in the orthography (8).

à travers 'through'

(French)

par (la) faute de / à faute de > faute de 'for want of'

du côté de $>$ du côté $>$ côté 'on the side of, concerning'

As can be seen in these examples, the reduction of complex adpositions can take different forms, mainly (a) morphosyntactic reduction via univerbation and (b) shedding, i.e. loss of constitutive elements. Though the lexical nucleus is typically maintained even when the complex adposition becomes a simple one, it can then be formally distinct from its source, as in the case of Italian attraverso 'through' (Hoelbeek 2017) (cf. Italian traverso 'transverse') or not, as in the case of German richtung 'towards' (Stathi, forthc.) (cf. German Richtung 'direction'). One question that arises in this connection is whether the tendency for complex adpositions to eventually become simple is important in the renewal of adpositional paradigms (cf. Svorou 1994).

However, looking into the systems of simple and complex adpositions in individual languages more closely, one may as well hypothesize that - at least in some languages - CAs form a more or less independent paradigm or a (sub-)category of their own. For instance, in German, the complex prepositions predominantly follow the productive pattern $[P \mathrm{~N} P$ / $\mathrm{CASE}_{\mathrm{GEN}}$ ], whose inventory may be more or less freely expanded to accommodate new members of the class: they serve to build prepositional phrases with adverbial functions, and they do not always have semantic equivalents in the class of simple adpositions. Importantly, from this inventory of complex prepositions, only rare exceptions proceed on the grammaticalization cline towards simple prepositions, whereas the majority of them either remain complex or become obsolete over time. Taking into account these synchronic and diachronic paradigmatic properties of complex adpositions, it could be argued that they pertain to a separate category with prototypical structure. Whether or not this idea represents a plausible theoretical embedding of complex adpositions cannot be answered in the context of this discussion, and will remain an question for further research.

\section{Complex nominal relators and other typological features}

From a typological perspective, it seems we might expect (at least) two types of relationships between nominal relators and other typological features of a language. The first one is the well-known tendency for SVO languages to have prepositions, and for SOV languages to have postpositions (see e.g. Dryer 2013a-b):

'Lyons (1967:302) observes that the difference between prepositions and postpositions is trivial and that 'many linguists would say that it is mere pedantry to maintain the terminological distinction'. Research on the order of meaningful elements carried out four 
years earlier (Greenberg 1963d) had established that this terminology is not all that trivial.' (Heine 1989:78).

The second is the obvious link between the global tendency of a language towards syntheticity or analyticity and its use of case markers vs adpositions to mark nominal relations. Thus, while varieties described in this book all seem to have morphologically and/or syntactically complex nominal relators, this complexity takes many forms. The word continuum appears in more than one chapter of this volume to describe the paradigms of CAs, and it seems safe to say that paradigms of nominal relators typically range from simple items to complex ones, in languages displaying such a category. We can posit a cline from morphologically and syntactically simple nominal relators (simple adpositions without case marking and simple case markers) to complex ones, some languages having both morphologically and syntactically complex nominal relation markers (see e.g. the variation between $\left[\mathrm{P}_{1}\right.$ (DET) $\mathrm{N} \mathrm{P}_{2}$ ] and $\left[\mathrm{P}_{1}\right.$ (DET) $\left.\mathrm{N}+\mathrm{CASE}\right]$ in German and Romanian, in chapters 2 and 3). The data from Permic (chapter 9) suggests that, in some cases, one could establish a gradient of complexity from syntax to morphology. Though the most obvious type of morphologically complex relators are combinations of case markers, such as those found in Permic, Estonian (chapter 8) or Basque (chapter 10), compound prepositions are sometimes transparent enough to license an analysis in terms of morphological complexity, e.g. in Serbian (chapter 3), Albanian (chapter 7) and Maltese (chapter 12). The opposition between morphological and syntactic complexity can be illustrated by the prevalence of $\left[\mathrm{P}_{1}\right.$ DET N $\left.\mathrm{P}_{2}\right]$ or [CASE + N-CASE] structures, as illustrated in Table 1 . The analysis of a construction as a Compound, rather than as a Simple or Complex adposition, is problematic, and may depend on the perspective adopted by the authors (more synchronic, or more diachronic): we maintained this distinction in Table 1, but highlighted the category in grey to show that it may have a different status.

Table 1: Degrees of complexity of nominal relators (in bold, underlined) within PPs (NP complements in italics)

\begin{tabular}{|c|c|c|c|c|}
\hline \multirow{3}{*}{ Use type } & \multirow{3}{*}{ Marker type } & \multicolumn{3}{|c|}{ Languages } \\
\hline & & \multirow{2}{*}{$\begin{array}{l}\text { without case } \\
\text { marking }\end{array}$} & \multicolumn{2}{|c|}{ with case marking } \\
\hline & & & $\begin{array}{c}\text { no semantic } \\
\text { differentiation }\end{array}$ & $\begin{array}{c}\text { semantic } \\
\text { differentiation }\end{array}$ \\
\hline \multirow{2}{*}{$\begin{array}{l}\text { Functional } \\
\text { (not a head, } \\
\text { grammatical } \\
\text { uses) }\end{array}$} & \multirow{6}{*}{ Simple } & $\underline{\text { PREP }}_{\underline{E}} N P$ & $N P \underline{-C}$ & \\
\hline & & Fr., Pt., En., Dt. & $\begin{array}{l}\text { Gr., Rm., Bs., Pm., Tk., } \\
\text { Al., Es., Gm., Sb. }\end{array}$ & - \\
\hline \multirow{7}{*}{$\begin{array}{c}\text { Lexical } \\
\text { (functions as a } \\
\text { head) }\end{array}$} & & $\underline{\text { PREP } N P}$ & $N P$-CASE ${ }^{\left(\text {STRUCTURAL }^{* *}\right)}$ & $N P$-CASE \\
\hline & & $\begin{array}{c}\text { Fr., Pt., En., Dt., } \\
\text { Mlt. }\end{array}$ & Gr., Rm.* & $\begin{array}{c}\text { Bs., Pm., Tk., Al., } \\
\text { Es., Gm., Sb. }\end{array}$ \\
\hline & & $\begin{array}{l}\text { PREP }_{N P_{z}} \\
\text { CASE }^{\text {(ARCHAIC) }}\end{array}$ & $\underline{\text { PREP }} N P_{\underline{-C A S E}}{ }^{(\text {STR })}$ & $\underline{\text { PREP }} N P$-CASE \\
\hline & & Dt. & Gr., Rm.*, Gm., Sb. & Gm., Sb. \\
\hline & \multirow{3}{*}{$\begin{array}{l}\text { Compound } \\
\text { (e.g. PP, } \\
\text { AdvP) }\end{array}$} & $\underline{\text { PREP }}_{\underline{1}} \underline{\text { PREP }}_{\underline{2}} N P$ & $\underline{\text { PREP }}_{1} \underline{\text { PREP }}_{\underline{2}} N P$-CASE & $N P$-CASE ${ }_{\underline{1}}$-CASE $_{\underline{2}}$ \\
\hline & & Fr., Pt., En., Mlt. & Sb. & Bs. \\
\hline & & ADVPREP NP & $\underline{\text { ADVPREP }} N P$-CASE $^{(\mathrm{STR})}$ & $N P \underline{\text { N-CASE }}$ \\
\hline
\end{tabular}




\begin{tabular}{|c|c|c|c|}
\hline & Sp., Pt., It. & Gr. & $\begin{array}{l}\text { Bs. (inanimate } \\
\text { nouns) }\end{array}$ \\
\hline \multirow{6}{*}{ Complex } & $\underline{\text { PREP }}_{1} \underline{\text { NPREP }}_{\underline{2}} N P$ & $\underline{\text { PREP }}_{\underline{1}} \underline{N} N P_{\text {-CASE }}{ }^{(\text {STR })}$ & $\underline{\mathbf{N} \text {-CASE } N P \text {-CASE }}$ \\
\hline & Fr., Pt., En. & Gr. & \\
\hline & - & - & NP-CASE N-CASE \\
\hline & & & Bs. \\
\hline & $\underline{\text { PREP }}_{1} \frac{\operatorname{detNPREP}}{N P} \underline{2}$ & - & $\underline{\text { PREPdetN } N P \text {-CASE }}$ \\
\hline & Fr., Pt., En. & & \\
\hline
\end{tabular}

Notes:

* in Modern Romanian, some Ps take the accusative, others the genitive, but there is no single $\mathrm{P}$ with the two cases.

** the default is that cases add a semantic value to the construction; in some instances, however, there seems to be no opposition between different cases, and thus no semantic value: we then consider them to have only a structural value, and they are noted $\mathrm{CASE}^{(\mathrm{STR})}$.

- the category is not attested / there is no corresponding category

A third relationship could be expected between typological features and CRs - CAs in particular: since languages with case markers often also have simple adpositions, one might think that there is some kind of (inverse) correlation between the presence of case marking in a language and its having complex adpositions: schematically, the first degree of complexity in a language with case marking and simple adpositions is the combination of the two, while in a language without case marking it is compound adpositions, as illustrated in Table 2.

\begin{tabular}{|c|c|c|}
\hline Degrees of complexity & Language with case marking & Language without case marking \\
\hline single marking & case & simple adposition \\
\hline double marking & case + simple adposition & compound adposition \\
\hline $\begin{array}{c}\text { complex marking } \\
\text { marker }\end{array}$ & case + compound adposition & complex adposition \\
\hline $\begin{array}{c}\text { highly complex } \\
\text { marking }\end{array}$ & case + complex adposition & \\
\hline
\end{tabular}

Table 2: Degrees of complexity and presence of case marking.

This is a very schematic view, since the complexity and weight of case marking vary greatly from one language to the next, as illustrated by the data on Romanian, German, Serbian, Greek, Albanian, Estonian, Permic, Basque and Turkish (chapters 2-4 and 6-11). If we do accept this idea, it could be thought that languages with case marking have less developed paradigms of CRs. Some languages do seem to fit this hypothesis, for instance Old French and Albanian (with case marking and limited paradigms of CRs) vs Modern French, English and Portuguese, for instance. The case of German, which has case marking and large paradigms of CAs - paradigms which are, in fact, quite comparable to those of Dutch and English -, seems to indicate that the hypothesis is at best partly valid. Besides, Serbian 
(chapter 3), which has an even more elaborate system of case marking, also has a large paradigm of CAs.

\section{The emergence of CAs in Europe}

From a diachronic perspective, the emergence of CRs is quite easy to understand, at least in very general terms. For instance, looking at adnominal relations in Indo-European languages, we can see a global paradigm shift from proto-Indo-European (with no case marking, see e.g. Meillet 1948:544) to a closed-class paradigm of case marking in IndoEuropean (8 cases, initially lexical elements which gradually grammaticalized to various extents, see e.g. Lehmann 1974:49, Haudry 1982:20, Meier-Brügger 2000:12). What is striking in the later evolution is that new relational elements keep stacking up onto these original 'simple' adnominal relation markers: first adverb-like elements (see e.g. Beekes 1995:218), which then become reanalyzed as simple prepositions (Giacalone Ramat and Ramat 1993:102) and end up, in quite a few Indo-European languages, replacing case marking altogether as adnominal relation markers. In this perspective, CAs constitute just another layer of complexity. This general trend could be analyzed as follows: at any point in time, a language typically has a closed-class paradigm for adnominal relation marking. But closed-class paradigms eventually prove to be functionally insufficient ${ }^{3}$, the need or desire to specify or disambiguate further the possible semantic relations triggering the use of new elements. ${ }^{4}$ Whatever the stage of evolution, the trend seems to be the same: a deficiency of an initial paradigm triggers an enlargement making it possible for language to respond to increasing communicative needs.

However, the case of CAs in European languages remains particularly interesting, because they appear to have emerged as an areal phenomenon (e.g. Popović 1966, Van der Horst 2013, Hüning 2014). Thus, their emergence could be the result of the 'natural' evolution described above - just another layer of complexity to remedy the limitations of closed-class paradigms - or it could be linked to socio-cultural changes which took place at some point between the Renaissance and Modern Times. It is quite widely accepted by now that the cultural proximity across the whole of Europe may have led to a slow but steady leveling of linguistic differences (Haspelmath 2001: 1506-1507), the outcome being what has been termed 'Standard Average European' (Whorf 1956 [1939], quoted in Van der Auwera 2011: 291). And it is quite clear that CAs have appeared in several European languages during the last few centuries: as noted for instance in the chapter on Romance, there are [PNP] constructions in the Middle Ages, but CAs to have emerged as a class (i.e. with consistent patterns and important type and token counts) only later on. Thus, for French, to take just one example, there is a striking contrast between Old and Middle French, on the one hand, and Classical and Modern French, on the other. In other chapters, slightly different periods are mentioned: $18^{\text {th }}$ and $19^{\text {th }}$ centuries in Serbian, $19^{\text {th }}$ century in the Germanic languages.

\footnotetext{
${ }^{3}$ Cf. for instance Hopper \& Traugott (1993:88): “As grammaticalized forms become increasingly syntacticized or morphologized they unquestionably cease over time to carry significant semantic or pragmatic meaning”. ${ }^{4}$ In the case of Indo-European, these elements were adverbs, accompanying the initial set of case markers. Once they were used frequently, these adverbs were reanalyzed not as accompanying case markers, but as specifying their meaning, and further as governing the noun phrase initially headed by case alone - a situation which is found in Classical languages, e.g. Latin and Ancient Greek. This is roughly how (simple) prepositions were introduced in the language system. In the next step, this renewed paradigm of nominal relation markers has also proven to be insufficient, which resulted in the broadening of the class either by combining simple prepositions in order to form compound ones, or by recruiting new markers in the nominal domain. A whole range of relational and spatial nouns were thus integrated, alone in an inflected form or in combination with a preposition, in the paradigm of nominal relation markers in order to express in a finer-grained way, at least in the first instance, various concrete relationships, and later many other kinds of semantic relations
} 
Another striking feature of the emergence of CAs in European languages is that two forces seem to have played an important role: cultural drift (Van der Horst 2013:182) and language contact. The use of CAs is strongly linked to formal registers and/or the Press, an aspect which has been noted for various languages and by several authors (see e.g. the chapters on Germanic and Serbian; cf. Benes 1974, Blumenthal 2018, Stefanowitsch forthc.). Popović (1966:195-196) namely writes that it is linked to "the development of modern sciences, administration and journalism”, a statement which sums up neatly the cultural trends possibly involved in the rise of CAs (see also Lehmann's "bureaucratic and journalistic jargon": Lehmann 1991:501). The transformation of Europe in the $18^{\text {th }}$ and $19^{\text {th }}$ centuries first and foremost in England, France and Germany, but also in neighbouring countries - was quite radical, not only in industrial terms but also in terms of society and politics (see e.g. Piel 1989:138 sq.). For one thing, there is the slow regression of Latin, which had been the language of culture, diplomacy and science for the whole period of the Middle-Ages, and well into the Renaissance. Latin may be said to have remained the language of prestige until the $17^{\text {th }}$ and even $18^{\text {th }}$ centuries (Febvre and Martin 1976); however, there was a slow but regular progression of vernacular languages in that period: more and more people came to have access to writing without mastering Latin, scientific works began appearing in French, English, German, Dutch, etc. The important industrialization process (with what could be called an "industrial Enlightenment”, see Mokyr 2009) could also have had an impact on language: as noted by Popplow (2016:282), this process brought on a set of interrelated developments resulting "in the fact that technical knowledge was no longer nearly exclusively embodied in an artisan [...] Towards the end of the early modern period, such formalized technical knowledge was collected, discussed, and taught in institutions such as scientific academies, economic societies, and engineering schools". Finally, in the $19^{\text {th }}$ century (and even more so in the early $20^{\text {th }}$ century), the press achieved a wide distribution, from some tens of thousands of copies around the middle of the $19^{\text {th }}$ century to hundreds of thousands at the turn of the century and millions shortly thereafter (Weill 1934).

The importance of language contact has also been noted in various chapters of the volume. The existence of similarities in cognate languages is quite obvious, and can be seen for instance in the chapters on Romance and Germanic; but the borrowing of CAs from (genealogically) more distant languages is noted in various chapters, e.g. on Breton, Serbian, Maltese and Greek; additionally, it is mentioned as a possibility in the chapter on Albanian. In the chapter on Estonian, though the emergence of CAs is not ascribed to language contact, the author does mention the importance of contact with German, Swedish, and Russian.

Two counter-arguments could be brought to this hypothesis that CAs might have emerged in European languages mainly as a result of a global cultural drift associated with close language contact across Europe. The first one is that, among the languages investigated in this volume, the importance of contact is not as clear in languages which do not have CAs but CRs: Turkish, Estonian, Basque, Maltese and Permic. For these languages, it would be interesting to dig further in order to check the possibility of an independent development of CRs. The second counter-argument is even more obvious: there are CAs outside Europe ${ }^{4}$. We address this in the following section.

\section{Beyond Europe}

Concerning simple nominal relators, previous studies (e.g. Svorou 1994, Hagège 2010) have shown that there are important differences across languages. These differences may for

\footnotetext{
${ }^{4}$ Of course, this is a counter-argument only if these CAs outside Europe developed independently from any similar 'cultural drift'.
} 
instance concern the type of items which encode nominal relations, mainly case suffixes and prepositions, but also postpositions, prefixes (much less common than case suffixes, according to Dryer 2013c) and relational nouns (typically with some items which grammaticalize into adpositions, see e.g. Heine 1989, DeLancey 1997). There are also important differences in paradigm size, with e.g. only one simple adposition in some languages, such as Burmese (Tibeto-Birman, Sino-Tibetan), Likpe (Kwa, Niger-Congo), Samoan (Eastern Malayo-Polynesian, Austronesian), Tagalog (Western Malayo-Polynesian, Austronesian), or Tzeltal (Mayan), and long lists in other languages (e.g. Romance languages, see Fagard 2006). One might expect similar variations for complex nominal relators. Indeed, the previous sections present a few core patterns: constructions with adpositions as relators, with case markers as relators, and with a combination of the two. The situation is actually even more complex, since the distinction between case markers and adpositions is not entirely discrete: rather, while some case markers are clearly affixes or even clitics, and some adpositions clearly independent words, quite a few items fall in-between these categories. For instance, functional adpositions may grammaticalize to the point that they resemble case markers in at least some respects, and some items can be analyzed both as case affixes and postpositions, for instance in Hungarian (Uralic; see Creissels 2006) or Korean (isolate; see Choi-Jonin 2008).

Complex nominal relators, as we define them, are apparently found in all languages having simple nominal relators. It is quite easy to find languages with adpositions which also have CAs, as in Malagasy. To give just a few examples, Malagasy (Austronesian) displays a construction which seems perfectly parallel to those described in this volume: alongside simple adpositions, which are typically quite polysemous, such as amy 'at' (9-10), there are several sequences of simple adposition and noun (sometimes in disuse, see Ferrand 1903:232), which can introduce an NP, as in (11).

\begin{tabular}{|c|c|c|c|c|}
\hline (9) & $\begin{array}{ll}\text { Dokotera } & \text { izy } \\
\text { Doctor } & \text { PRO }\end{array}$ & $\begin{array}{l}\text { ka } \\
\text { and }\end{array}$ & $\begin{array}{ll}\text { manao } & \text { fit } \\
\text { do } & \text { vi }\end{array}$ & $\begin{array}{ll}\text { ihana } & \mathrm{ny} \\
& \mathrm{D}\end{array}$ \\
\hline & 'He's a doctor and & jisits peo & le on the boat' & Fugier $1 \mathrm{~s}$ \\
\hline (10) & $\begin{array}{l}\text { An-katezerana } \\
\text { with-anger }\end{array}$ & $\begin{array}{l}\text { no } \\
\text { EMPH }\end{array}$ & $\begin{array}{l}\text { itenenan } \\
\text { speak.PASS }\end{array}$ & $\begin{array}{l}-d R a s o a \\
\text { Rasoa }\end{array}$ \\
\hline
\end{tabular}

(Malagasy)
olona eny an-tsambo person there on- boat

(Malagasy)

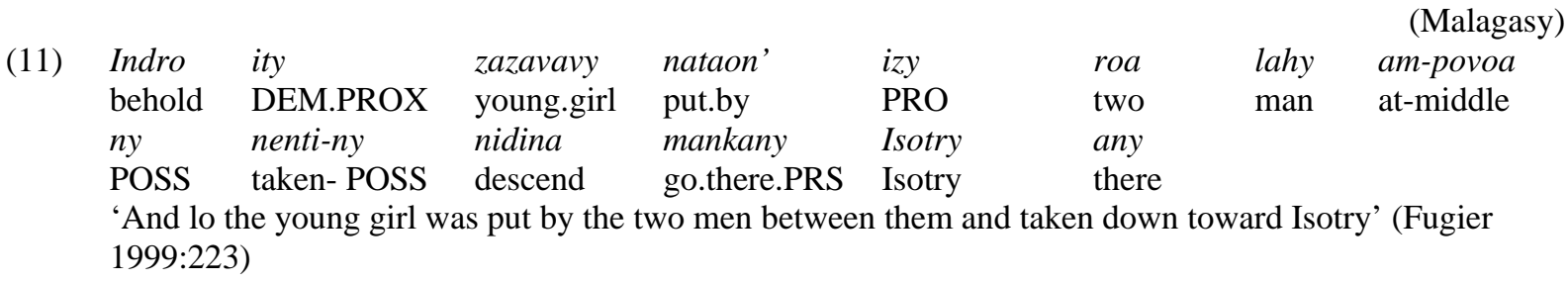

Another example with simple and complex adpositions is Teochew, an isolating, SVO Southern Min dialect of Chinese. Alongside simple prepositions such as $\left[\mathrm{pu}_{\mathrm{n}}{ }^{33}\right]$ 'at, by', $d o^{5}$ 'at, by, in' or [dui $\left.{ }^{213}\right]$ 'by, via, along', Teochew has constructions with a simple preposition and a relational noun, the latter specifying the position of the target with respect to the landmark (see My Dung, in prep.), as in (12-13).

\footnotetext{
${ }^{5}$ Some examples are adapted from Fortis \& Fagard (2010).
} 
(12)

$$
\begin{array}{lll}
\text { do }^{6} \quad c w j^{5} & d^{2} j^{2} \\
\text { at table } & \text { top } \\
\text { 'on the table' } &
\end{array}
$$

(13) $d o^{6} \quad \mathrm{cwj}^{5} \quad \mathrm{bin}^{1} \mathrm{tao}^{2}$

(Teochew) at table side 'next to the table'

Languages with case marking such as Japanese also display sequences which correspond to what we call CRs, in which a nominal or adverbial nucleus (naka in (14)) is linked to the complement (ie 'house') by a genitive case marking (-no) and to the rest of the sentence by a locative case marking $(-d e){ }^{6}$

$$
\begin{aligned}
& \begin{array}{lllll}
\text { Mary } & \text { wa } & \text { ie-no } & \text { naka-de } & \text { hashit-ta. } \\
\text { Mary } & \text { TOP } & \text { house.GEN } & \text { inside.LOC } & \text { run.PRS }
\end{array} \\
& \text { 'Mary was running in the house.' }
\end{aligned}
$$

(Japanese)

Other types of CRs are attested, such as the combination of a nucleus and a case marker, illustrated in (15) by Jaminjung (Yirram, Mirndi), or the combination of case markers illustrated in (16) by Tabasaran (Lezgic, Nakh-Daghestanian), including rare types of case marking as in Maasai (Nilotic, Eastern Sudanic, Nilo-Saharan), in which the case is marked by tone (17).

$$
\begin{array}{llll}
\text { dibard } & \text { ga-w-ijga } & \text { walthub } & \text { langiny-bina. } \\
\text { jump } & \text { 3SG-FUT-go } & \text { inside } & \text { wood-ALL } \\
\text { 'It will jump into the trees.' (Schultze-Berndt 2000: 425) }
\end{array}
$$

As noted by Fortis and Fagard (2010), in languages with only one simple adposition, this adposition has a generic meaning, and is used alone, i.e. with no other adnominal marker, only for canonical spatial relations (18): When further specification is needed, it may be done with the help of spatial nouns (19) or positionals, thus yielding CRs.

$$
\begin{array}{llllll}
\text { na } & \text { sa } & \text { Silya } & \text { Ang } & \text { kanya-ng } & \text { damit. } \\
\text { REAL } & \text { PREP } & \text { chair } & \text { NOM } & \text { 3SG.OBL-LNK } & \text { dress }
\end{array}
$$

'Her dress is / was on the chair.'

na sa harap $n g$ silya siya.

(Tagalog) 
REAL PREP front GEN chair 3SG.NOM

'S/he is in front of the chair.'

In (19), the complexity is purely syntactic; examples (20-21) (Wilkins 2006:33) illustrate for Arrernte (Central Pama-Nyungan) the existence of morphological complexity (20) or both morphological and syntactic (21) (also (10), above).

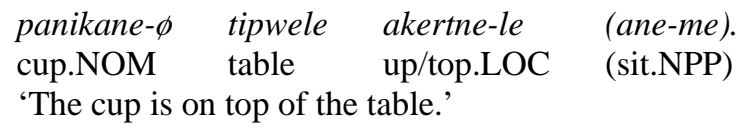

(Arrernte)

$\begin{array}{lll}\text { (21) alkngenthe-ø } & \text { tipwele-nge } & \text { akertne-le. } \\ \text { light.NOM } & \text { table.ABL } & \text { up/top.LOC }\end{array}$

(Arrernte)

'The lamp is above the table.'

In Korean (isolate), there is a debate concerning the status of adnominal markers (see ChoiJonin 2008), which are post-posed and could be analyzed as case markers or as postpositions (as we mentioned for Hungarian) - some linguists consider only a subparadigm to be actual case markers, while the others should be analyzed as postpositions. While they appear to be morphologically simple in synchrony (22-23), some seem to arise from the simplification of complex markers. For instance, diachronic studies show that the ablativeinessive eyse results from the combination of the locative ey and an ancient verb se 'to exist' (24); a similar analysis could be proposed for the exceptive (25), based on pakk 'outside' in the locative case ey.

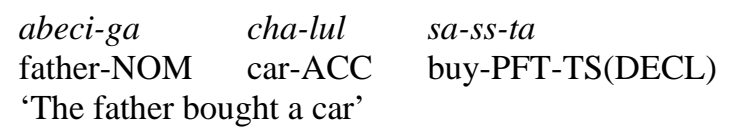

(25) ne-pakkey eps-ta you-except not.exist-ST(DECL) 'There's only you' ${ }^{6}$

(Korean)

Hagège (2010) restricts what he calls “Complex Adps” to "a word-type in which one of the constituent parts is an Adp, and the other is a case affix, in a form required by the Adp" (Hagège 2010: 38-39) ${ }^{7}$.

\footnotetext{
${ }^{6}$ Examples (22-25) are from Choi-Jonin (2008 and p.c.).
} 
As further noted by Fortis and Fagard (2010), "In a number of languages, a part which functions as a spatial noun must be 'locativized' (receive a locative marker)" (cf. Heine 1989: 103-4 for Bantu languages), thus also yielding CRs, as in Swahili (Bantoid, Benue-Congo, Niger-Congo) mbele 'front' < locative class prefix mu- + *-bele 'breast').

It would be interesting to see whether rare systems of adpositions, such as inpositions - as found in Anindilyakwa (Gunwinyguan; Dryer 2013a) -, also include CRs (26).

...narri-ng-akbilyang-uma [eyukwujiya=manja eka]

$\ldots \mathrm{NC}_{1}$.PL-NC ${ }_{2}$-stick.to.end-TA [small=LOC stick]

'... they stuck them (the feathers) to a little stick.' (Groote Eylandt Linguistics-langwa 1993: 202)

While prepositions and case-marking systems are widely attested in the languages of the world, a question that comes to mind is what would correspond to a CR in a language which has neither.

According to DeLancey (2005), Klamath (Klamath-Modoc, Penutian) probably has no adposition, as spatial relations are encoded in the verb, in Locative Directive Stems, as in (27).

$\begin{array}{llll}\text { c-eq'ya } & \text { honk } & \text { doo } & \text { wqepl'aqs-dat. } \\ \text { sit-in.doorway } & \text {-DEM } & \text { over.there } & \text { summer.house-LOC } \\ \text { 'She sat at the door of the house.' (Barker } & \text { 1963:4.1;107) }\end{array}$

(Klamath)

However, Klamath does have a case marking system. Besides, Locative Directive Stems constitute a very large paradigm - containing 133 items, according to DeLancey (2000, following Barker 1964): while they "do not represent any familiar or well-understood category" (DeLancey 2000:71), DeLancey shows that they are verbal "at least in origin" (ibid.). Dryer (2013a) notes that languages with no adpositions "are most common in Australia and North America”. Those that have case markers, such as Yidiny (Northern PamaNyungan; Dixon 1977), could have CCs, as described e.g. in Permic (Chapter 9). But in languages which have neither adpositions nor case markers, such as Kutenai (isolate; western North America), it would be interesting to see the range of linguistic items used for nominal relations. More generally, it would be interesting to test the link between the type of items found in a language for marking nominal relations (case markers, adpositions, relational nouns), their position (in front of the complement, behind it, around it or infixed, i.e. within the complement itself), their number (i.e. the paradigm size) and the respective proportions of simple vs complex markers.

To conclude, let us turn back to our initial methodological decisions: in this volume, we chose to focus on a limited area of the world - Europe -, to proceed, as much as possible, within a common theoretical framework, and to ask authors to combine (wherever such data were accessible) synchronic and diachronic approaches. We believe that this approach has

\footnotetext{
${ }^{7}$ Excluding from the core category, i.e. what he calls Complex Adps proper, marginal instances such as phenomena of case heaping ("a phenomenon involving adnominal complements marked by a succession of two or more contiguous case markers or case marker-like elements", Hagège 2010:39), case agreement ("situations in which two case-markers seem to be applied to the same element”, Hagège 2010:40) and case association (in which two words are marked with the same case, one "signaling location in general, while the other refers to the specific orientation of the located entity" (Hagège 2010: 42-43); this "can be considered as a type of double marking” (Hagège 2010:43)).
} 
yielded fruitful results: it has made it possible to provide a good coverage of the phenomenon under investigation, i.e. Complex Adpositions and more widely Complex Nominal Relators, and to bring to light interesting phenomena, raising new research questions or at least leading us to reframe the questions we had started out with. It seems quite clear that, being half-way between lexicon and grammar, CAs uniformly play a fundamental structuring role in languages, whatever their position in adpositional phrases, their patterns of formation, or their paths of evolution. However, it is equally obvious that there is still substantial work to be done: first, in order to explain by testing, for instance, the 'cultural drift' hypothesis, which has only been briefly touched upon here, second, in order to probe the universality or, at the very least, the communality, outside Europe, of the main construction schemas of complex adnominal relations, as revealed in this volume, and third in order to grasp the whole range of functional and semantic relations that CAs convey across languages. We hope that the results of this volume are enough to open this new line of research.

\section{Abbreviations}

2, 3: second, third person

ABL: ablative

ACC: accusative

ALL: allative

CA: complex adposition

INT: interrogative

LNK: linker

LOC: locative

M: masculine

NC: noun class

NEG: negation

NOM: nominative
CR: complex nominal relator

DAT: dative

DECL: declarative

DEM: demonstrative

$\mathrm{N}_{\text {rel: }}$ relational noun

OBL: oblique

PASS: passive

PFT: perfect

PL: plural

POSS: possessive

PREP: preposition
DET: determiner

EL: elative

FUT: future

GEN: genitive

IMP: imperative

PRS: present

REAL: realis

SG: singular

TA: tense/aspect

TOP: topicalizer

TS: terminal suffix

TSL: translative

\section{References}

Auwera, Johan van der (ed.). 1998. Adverbial constructions in the languages of Europe. Berlin \& New York: Mouton de Gruyter.

Barker, Muhammad Abd-al-Rahman. 1963. Klamath Texts. Berkeley \& Los Angeles: University of California Press.

Barker, Muhammad Abd-al-Rahman. 1964. Klamath Grammar. Berkeley \& Los Angeles: University of California Press.

Beekes, Robert. 1995. Comparative Indo-European linguistics: an introduction. Amsterdam \& Philadelphia: John Benjamins.

Benes, Eduard. 1974. Präpositionswertige Präpositionalfügungen. In Ulrich Engel \& Paul Grebe (eds.), Sprachsystem und Sprachgebrauch: Festschrift für Hugo Moser zum 65. Geburtstag (Sprache der Gegenwart 33), vol. 1, 33-52. Düsseldorf: Schwann.

Blumenthal, Peter. 2018. Locutions prépositionnelles " phénoménologiques ». In Céline VaguerFekete (ed), Quand les formes prennent sens. Hommage à Danielle Leeman, 195-204. Limoges: Lambert-Lucas.

Brinton, Laurel \& Elizabeth C. Traugott. 2005. Lexicalization and language change. Cambridge: Cambridge University Press.

Choi-Jonin, Injoo. 2008. Particles and postpositions in Korean. In Dennis Kurzon \& Silvia Adler (eds.), Adpositions: Pragmatic, semantic and syntactic perspectives, 133-170. Amsterdam \& Philadelphia: John Benjamins.

Cifuentes Honrubia, José Luis. 2003. Locuciones prepositivas - sobre la gramaticalización preposicional en español. Alicante: Universidad de Alicante. 
Comrie, Bernard \& Maria Polinsky. 1998. The great Daghestanian case hoax. In Anna Siewierska \& Jae Jung Song (eds.), Case, Typology and Grammar, 95-113. Amsterdam \& Philadephia: John Benjamins.

Creissels, Denis. 2006. Suffixes casuels et postpositions en hongrois. Bulletin de la Société de Linguistique de Paris 101(1), 225-272.

DeLancey, Scott. 1997. Grammaticalization and the gradience of categories: Relator nouns and postpositions in Tibetan and Burmese. In Joan Bybee, John Haiman \& Sandra A. Thompson (eds.), Essays on Language Function and Language Type, 51-69. Amsterdam \& Philadephia: John Benjamins.

DeLancey, Scott. 2000. Argument structure of Klamath bipartite stems. In Andrew Simpson (ed.), Proceedings of the 26th Annual Meeting of the Berkeley Linguistics Society: Special Session: Syntax and Semantics of the Indigenous Languages of the Americas, 15-25. Berkeley: Berkeley Linguistic Society.

DeLancey, Scott. 2005. Adposition as a non-universal category. In Zygmunt Frajzyngier, Adam Hodges \& David Rood (eds.), Linguistic diversity and language theories, 185-202. Amsterdam \& Philadelphia: John Benjamins.

Di Meola, Claudio. 2000. Die Grammatikalisierung deutscher Präpositionen. Tübingen: Stauffenburg.

Dixon, Robert M. W. 1977. A Grammar of Yidin. (Cambridge Studies in Linguistics, 19.) Cambridge: Cambridge University Press.

Dryer, Matthew S. 2013a. Order of Adposition and Noun Phrase. In Matthew S. Dryer \& Martin Haspelmath (eds.), The World Atlas of Language Structures Online. Leipzig: Max Planck Institute for Evolutionary Anthropology.

Dryer, Matthew S. 2013b. Order of Subject, Object and Verb. In Matthew S. Dryer \& Martin Haspelmath (eds.), The World Atlas of Language Structures Online. Leipzig: Max Planck Institute for Evolutionary Anthropology.

Dryer, Matthew S. 2013c. Position of Case Affixes. In Matthew S. Dryer \& Martin Haspelmath (eds.), The World Atlas of Language Structures Online. Leipzig: Max Planck Institute for Evolutionary Anthropology.

Fagard, Benjamin. 2006. Evolution sémantique des prépositions dans les langues romanes: illustrations ou contre-exemples de la primauté du spatial ? PhD Thesis, University of Paris 7.

Febvre, Lucien \& Henri-Jean Martin. 1997 [1976]. The Coming of the Book. The Impact of Printing 1450-1800. London \& New York: Verso.

Ferrand, Gabriel. 1903. Essai de grammaire malgache. Paris: E. Leroux.

Fortis, Jean-Michel \& Benjamin Fagard. 2010. Space in language, Summer School on Linguistic Typology. (online: http://htl-test.linguist.univ-paris-diderot.fr/Fortis).

Fugier, Huguette. 1999. Syntaxe malgache. Louvain-la-neuve: Peeters.

Giacalone Ramat, Anna \& Paolo Ramat. 1993. Le lingue indoeuropee. Bologna: Il Mulino.

Giacalone Ramat, Anna \& Paul Hopper (eds.). 1998. The Limits of grammaticalization. Amsterdam \& Philadelphia: John Benjamins.

Greenberg, Joseph H. 1963. Universals of language. Cambridge, Mass.: MIT Press.

Hagège, Claude. 2010. Adpositions. Oxford: Oxford University Press.

Haspelmath, Martin. 2001. The European linguistic area: Standard Average European. In Martin Haspelmath, Ekkehard König, Wulf Oesterreicher \& Wolfgang Raible (eds.), Language Typology and Language Universals, 1492-1510. Berlin: De Gruyter Mouton.

Haudry, Jean. 1982. Préhistoire de la flexion nominale en indo-européen. Lyon: Institut d'études indoeuropéennes de l'université Jean Moulin.

Heine, Bernd. 1989. Adpositions in African languages. Linguistique Africaine 2. 77-127.

Hoelbeek, Thomas. 2017. The Evolution of Complex Spatial Expressions within the Romance Family. Leiden: Brill.

Hoffmann, Sebastian. 2004. Are Low-Frequency Complex Prepositions Grammaticalized? On the Limits of Corpus Data - and the Importance of Intuition. In Hans Lindquist \& Christian Mair (eds.), Corpus Approaches to Grammaticalization in English, 171-210. Amsterdam \& Philadelphia: John Benjamins. 
Hoffmann, Sebastian. 2005. Grammaticalization and English Complex Prepositions. A corpus-based analysis. London \& New York: Routledge.

Horst, Joop van der. 2013. Taal op drift: lange-termijnontwikkelingen in taal en samenleving. Amsterdam: Meulenhoff.

Hüning, Matthias. 2014. Over complexe preposities en convergentie [About complex prepositions and convergence]. In Freek Van de Velde, Hans Smessaert, Frank Van Eynde \& Sara Verbrugge (eds.), Patroon en argument. Een dubbelfeestbundel bij het emeritaat van William Van Belle en Joop van der Horst [Pattern and argument. A double festschrift on the occasion of of the retirements of William Van Belle and Joop van der Horst], 433-445. Leuven: Universitaire Pers Leuven.

Kurzon, Dennis \& Silvia Adler (eds.). 2008. Adpositions: Pragmatic, semantic and syntactic perspectives. Amsterdam \& Philadelphia: John Benjamins.

Lehmann, Christian. 1991. Grammaticalization and related changes in contemporary German. In Elizabeth C. Traugott \& Bernd Heine (eds.), Approaches to grammaticalization, vol. 2, 493- 535. (Typological Studies in Language 19). Amsterdam \& Philadelphia: John Benjamins.

Lehmann, Christian. 2015 ( $3^{\text {rd }}$ edition). Thoughts on Grammaticalization. Berlin: Language Science Press.

Lehmann, Winfred. 1974. Proto-Indo-European Syntax. Austin: University of Texas Press.

Libert, Alan. 2013. Adpositions and Other Parts of Speech. Frankfurt am Main: Peter Lang.

Lightfoot, Douglas J. 2005. Can the lexicalization/ grammaticalization distinction be reconciled? Studies in language 29/3, 583-615.

Lindqvist, Christer. 1994. Zur Entstehung der Präpositionen im Deutschen und Schwedischen. Tübingen: Max Niemeyer Verlag.

Linguistics-langwa, Groote Eylandt. 1993. Eningerribirra-langwa jurra [Book about all sorts of things]. Angurugu: Groote Eylandt Linguistics.

Lyons, John. 1967 / 1977. Semantics, 2 vol., Cambridge: Cambridge University Press.

Meier-Brügger, Michael. 2000. Indogermanische Sprachwissenschaft. $7^{\text {th }}$ edn. Berlin \& New York: Walter de Gruyter.

Meillet, Antoine. 1948. Linguistique historique et linguistique générale. Paris: Champion.

Mokyr, Joel. 2009. The Enlightened Economy. An Economic History of Britain, 1700-1800. New Haven: Yale University Press.

Moreno Cabrera, Juan C. 1998. On the relationship between grammaticalization and lexicalization. In Anna Giacalone Ramat \& Paul Hopper (eds.), The Limits of grammaticalization, 211-227. Amsterdam \& Philadelphia: John Benjamins.

Piel, Jean. 1989. Esquisse d'une histoire comparée des développements dans le monde jusque vers 1850. Nanterre: Erasme.

Popović, Ljubomir 1966. Predloški izrazi u savremenom srpskohrvatskom jeziku [Phrasal prepositions in contemporary Serbian]. Naš jezik [Our language], XV, vol. 3-4. 195-220.

Popplow, Marcus. 2016. Technology and technical knowledge in the debate about the "great divergence”. Histoire et Sciences Humaines 4: L'Europe technicienne. XVe-XVIIIe siècle. Artefact. Techniques. Rennes: Presses Universitaires de Rennes, 275-286.

Prévost, Sophie \& Benjamin Fagard. 2007. Grammaticalisation et lexicalisation: la formation d'expressions complexes. Langue française 156. 3-8.

Schultze-Berndt, Eva. 2000. Simple and complex verbs in Jaminjung. A study of event categorisation in an Australian language. Nijmegen: University of Nijmegen. (= MPI Series in Psycholinguistics, $14)$.

Schwenter, Scott \& Elizabeth C. Traugott. 1995. The semantic and pragmatic development of substitutive complex prepositions in English. In Andreas Jucker (ed.), Historical pragmatics, 243273. Amsterdam: John Benjamins.

Stathi, Katerina. forthc. Die Entstehung der komplexen Präposition in Richtung im Deutschen: Zur Emergenz und Verfestigung von Konstruktionen. In Alexander Lasch \& Alexander Ziem (eds.), Konstruktionsgrammatik VI. Historische Konstruktionsgrammatik: Konvergenzen und Divergenzen im Sprach- und Konstruktionswandel. Tübingen: Stauffenburg. 
Stefanowitsch, Anatol. forthc. Complex prepositions of contrast and opposition in English. In Marcin Grygiel and Barbara Lewandowska-Tomaszczyk (eds.), Contrast and analogy in language: Perspectives from cognitive linguistics. Amsterdam \& Philadelphia: John Benjamins.

Svorou, Soteria. 1994. The Grammar of Space. Amsterdam \& Philadelphia: John Benjamins.

Tucker, Archibald N. \& John Tompo Ole Mpaayei. 1955. A Maasai Grammar with Vocabulary. Leyden: Publications of the African Institute / London: Longmans, Green \& Co.

Weill, Georges. 1934. Le journal. Origines, évolution et rôle de la presse périodique. Paris: La renaissance du livre.

Whorf, Benjamin, 1956. Language, Thought and Reality. Selected Writings of Benjamin Lee Whorf. Edited by John B. Carroll. Cambridge, Mass.: MIT Press.

Wilkins, David. 2006. Towards an Arrernte grammar of space. In Stephen Levinson \& David Wilkins (eds.), Grammars of Space: Explorations in Cognitive Diversity, 24-62. Cambridge: Cambridge University Press. 